\title{
Bacterial Brown Pit, a New Disease of Edible Mushrooms Caused by Mycetocola sp.
}

\author{
Mozhde Hamidizade, ${ }^{1}$ S. Mohsen Taghavi, ${ }^{1}$ Samuel J. Martins, ${ }^{2}$ Rachel A. Herschlag, ${ }^{2}$ Kevin L. Hockett, ${ }^{2}$ Carolee T. Bull, ${ }^{2}$ \\ and Ebrahim Osdaghi ${ }^{1, \dagger}$ \\ ${ }^{1}$ Department of Plant Protection, College of Agriculture, Shiraz University, Shiraz 71441-65186, Iran \\ ${ }^{2}$ Plant Pathology \& Environmental Microbiology Department, The Pennsylvania State University, University Park, PA 16802, \\ U.S.A.
}

\begin{abstract}
From September to December 2018, commercial button mushroom (Agaricus bisporus) farms in central Iran were surveyed to monitor the causal agent(s) of browning and blotch symptoms on mushroom caps. In addition to dozens of pseudomonads (i.e., Pseudomonas tolaasii and Pseudomonas reactans), six slow-growing gram-positive bacterial strains were isolated from blotched mushroom caps. These bacteria presented as creamy white, circular, smooth, nonfluorescent, and shiny colonies with whole margins resembling members of Microbacteriaceae (Actinobacteria). All of the actinobacterial strains were aggressively pathogenic on cut cap surface of two edible mushrooms (i.e., A. bisporus and Pleurotus eryngii), inducing brown pit symptoms $48 \mathrm{~h}$ postinocula-

Fusarium spp., and Phytopythium sp.). Phylogeny of $16 \mathrm{~S}$ ribosomal RNA and multilocus sequence analysis of six housekeeping genes (i.e., atpD, dnaK, gyrB, ppK, recA, and rpoB) revealed that the bacterial strains belong to the actinobacterial genus Mycetocola spp., whereas the species status of the strains remains undetermined. Mushroom-associated Mycetocola species were previously reported to be capable of detoxifying tolaasin, a toxin produced by $P$. tolaasii, whereas the strains isolated in this study did not show tolaasin detoxification activities. Altogether, this is the first report of a mushroom disease caused by an actinobacterial species, and "bacterial brown pit" was assigned as the common name of the disease.
\end{abstract} tion. The strains did not induce symptoms on the vegetables tested (i.e., carrot, cucumber, and potato), and they did not affect the growth of mycelium of tested plant-pathogenic fungi (i.e., Acremonium sp.,
Keywords: Actinobacteria, Agaricus bisporus, button mushroom, Coryneform bacteria, emerging disease, Microbacteriaceae, Pleurotus eryngii
During the past decades, commercial mushroom cultivation has been a fast-growing industry around the globe in part because of the relatively low price and high nutritional values of edible mushrooms in comparison with the conventional protein resources for human diet (FAOSTAT 2018). Button mushroom (Agaricus bisporus) dominates the edible mushroom market in most of the western countries followed by oyster mushroom (Pleurotus ostreatus), which is more prevalent in Asian countries (FAOSTAT 2018; Osdaghi et al. 2019). Although a range of abiotic parameters (i.e., relative humidity, temperature, and $\mathrm{CO}_{2}$ concentration in the room as well as the quality of compost and casing soil) were shown to play a decisive role in the productivity of the farm, biotic constraints (i.e., bacterial, fungal, and viral agents) have also had a significant impact on mushroom production (Fletcher and Gaze 2007; Osdaghi et al. 2019). Although the viral agents have sporadically been reported to cause economic crop losses (Eastwood et al. 2015), a number of fungal pathogens are capable of infecting edible mushrooms in a destructive manner. Wet bubble disease caused by Mycogone perniciosa, dry bubble caused by Lecanicillium spp., green mold caused by Trichoderma spp., and cobweb caused by Cladobotryum spp. are considered important fungal diseases of edible mushrooms around the world (Błaszczyk et al. 2013; Fletcher and Gaze 2007; Grogan 2006; Ware 1933).

${ }^{\dagger}$ Corresponding author: E. Osdaghi; eosdaghi@shirazu.ac.ir

Funding: Financial support for this study was coprovided by Shiraz University and College of Agricultural Sciences, Pennsylvania State University.

*The $\boldsymbol{e}$-Xtra logo stands for "electronic extra" and indicates that two supplementary figures are published online.

The author(s) declare no conflict of interest.

Accepted for publication 9 December 2019.

(C) 2020 The American Phytopathological Society
As for the bacterial agents, Pseudomonas tolaasii is the most wellstudied causal agent of a group of diseases referred to as bacterial blotch. P. tolaasii remains the most widespread pathogen of edible mushrooms since its first description in 1915 (Tolaas 1915), and bacterial blotch is still considered to be the most important mushroom disease in terms of economic loss and quality reduction. The disease significantly reduces the marketability of mushrooms owing to the discoloration of cap surface to a dark yellow or brown and a change in the texture (Osdaghi et al. 2019). However, several other pseudomonads are also responsible for similar bacterial blotch symptoms on the crop. For instance, Pseudomonas agarici causing drippy gill or yellow blotch (Young 1970), Pseudomonas costantinii causing brown blotch (Munsch et al. 2002), and two additional species with the taxonomically informal (invalid) names Pseudomonas reactans (Iacobellis and Lo Cantore 2003) and Pseudomonas gingeri (causing ginger blotch) (Wong and Preece 1982) are responsible for mushroom cap discoloration (Godfrey et al. 2001; Sajben et al. 2011; Schisler et al. 1968). Pathogenicity of $P$. tolaasii on mushroom caps depends on the biosynthesis of a low-molecular weight lipodepsipeptidide called "tolaasin," which causes mushroom cap browning and blotch symptoms (Lelliott et al. 1966; Nair and Fahy 1973). Tolaasin acts as a biosurfactant and forms ion channels to disrupt the plasma membrane of mushroom cells, allowing $P$. tolaasii access to cell nutrients (Nutkins et al. 1991). However, the pathogenicity mechanisms of the other pseudomonads (as mentioned above) mostly remain undetermined. Additionally, enterobacterial species (i.e., Ewingella americana [causing internal stipe necrosis] and Serratia liquefiiciens [causing yellow blotch]) were reported to infect edible mushrooms (Chowdhury et al. 2007).

From September to December 2018, severe browning and blotch symptoms were frequently observed on commercially grown mushrooms in the central provinces of Iran. Mushroom caps with symptoms resembling bacterial blotch disease and suspected to be infected with a bacterial agent were collected from the farms and subjected to further analyses. As a result, we have isolated dozens of pseudomonad strains from the symptomatic caps, which were identified as $P$. tolaasii and $P$. reactans, as well as a number of 
fluorescent pseudomonads belonging to Pseudomonas putida species complex (Hamidizade 2019). Additionally, six atypical bacterial strains were recovered from the symptomatic caps in Alborz and Tehran provinces. The later strains were shown to be highly pathogenic on the cut surface of mushroom caps. Preliminary observations (i.e., gram reaction and colony characteristics on culture media) (Schaad et al. 2001) suggested that the bacterial strains were resembling members of Microbacteriaceae (Actinobacteria). The family Microbacteriaceae comprises various genera and species, among which are several subspecies and pathovars of Clavibacter michiganensis (Davis et al. 1984) and Curtobacterium flaccumfaciens (Collins and Jones 1983), respectively, as well as different species of Leifsonia spp. (Evtushenko et al. 2000) and Rathayibacter spp. (Zgurskaya et al. 1993) that are considered economically important plant pathogens. Furthermore, mushroom-associated actinobacterial strains belonging to the family Microbacteriaceae and possessing antagonistic activity against the mushroom pathogen $P$. tolaasii were previously reported to decrease the severity of bacterial blotch disease on mushroom caps (Tsukamoto et al. 1998, 2001). However, so far, no gram-positive bacterial pathogen was described to infect edible mushrooms (Osdaghi et al. 2019).

The purposes of this study were to identify and characterize six actinobacterial strains isolated from symptomatic mushroom caps in Iran. For this objective, we identified the strains using the morphological characteristics and phenotypic features as well as the phylogeny of $16 \mathrm{~S}$ ribosomal RNA (rRNA) and multilocus sequence analysis (MLSA) of six housekeeping genes (i.e., atpD, dnaK, gyrB, $\mathrm{ppK}$, recA, and rpoB). Furthermore, pathogenicity and host range of the bacterial strains were assessed on various edible mushroom species. Reactions on vegetables and inhibition of mycelium of several filamentous fungi were also assessed. We also evaluated the bacterial strains isolated in this study for their interaction with $P$. tolaasii via coinoculation on mushroom caps and potato tuber discs. These analyses led to the description of a new bacterial disease on edible mushrooms caused by Mycetocola sp., for which we propose the term "bacterial brown pit" as a common name.

\section{Materials and Methods}

Surveys, sampling, and bacterial strains. Bacterial strains used in this study (Table 1) were isolated from symptomatic button mushroom caps collected from September to December 2018 from commercial farm surveys in central Iran (i.e., Alborz and Tehran provinces). This study follows a countrywide survey for monitoring the status of bacterial diseases of commercially grown edible mushrooms in the country (Hamidizade 2019). Surveying strategy and sampling procedure were the same as described previously (Hamidizade 2019). In brief, commercial mushroom farms were surveyed in all of the first, second, and third breaks of the growing process when the average diameters of mushroom caps were at least 2 to $3 \mathrm{~cm}$ (Osdaghi et al. 2019). Symptomatic mushroom caps possessing brown discoloration and blotch symptoms were harvested and brought to the laboratory inside paper bags under cool temperature. Symptomatic caps were washed under running tap water to remove the soil particles from the surface and rinsed three times in sterile distilled water (SDW). Small portions of symptomatic cap tissues were aseptically cut using a sterile scalpel and macerated in a few drops of SDW using a sterile mortar and a pestle. A loopful of the resulting suspensions was streaked simultaneously onto each of nutrient agar (NA), yeast extract peptone glucose agar (YPGA), and King's B (KB) media to broaden the range of isolated bacterial strains as recommended previously (King et al. 1954; Schaad et al. 2001). The plates were incubated at $27^{\circ} \mathrm{C}$ for 3 to 4 days, and the resulting colonies were purified by multiple streaking onto fresh medium. The bacterial strains were resuspended in SDW and stored at $4^{\circ} \mathrm{C}$ for further use; they were maintained in $15 \%$ glycerol at $-70^{\circ} \mathrm{C}$ for long-term storage. Although most of the bacterial strains isolated from symptomatic mushroom caps were identified as pseudomonads (Hamidizade 2019), here we describe the phenotypic, genotypic, and pathogenicity features of six atypical slow-growing bacterial strains isolated in central Iran (Table 1).

Phenotypic characterization of the strains. The six atypical bacterial strains were subjected to phenotypic and biochemical tests as recommended by Schaad et al. (2001). Gram reaction, catalase activity, colony characteristics on yeast extract-dextrose-calcium carbonate (YDC) agar medium, growth on $0.1 \%$ triphenyl tetrazolium chloride (TTC), fermentation of melezitose, utilization of citrate, and hydrolysis of Tween 80 were evaluated as described previously (Schaad et al. 2001). Furthermore, the levan production, oxidase, potato soft rot, arginine dihydrolase, and hypersensitive reaction (HR) in tobacco leaves scheme was determined as recommended previously (Lelliott et al. 1966). Potato soft rot and HR were evaluated on potato (Solanum tuberosum 'Spirit') tuber discs and tobacco ( $\mathrm{Ni}$ cotiana tabacum 'Turkish') leaves, respectively, using the bacterial suspension from a 48-h-old culture on YPGA medium at a concentration of $10^{8} \mathrm{CFU} / \mathrm{ml}$ as described previously (Ansari et al. 2019b). Reference strains of P. tolaasii (CFBP 8707) and P. reactans (CFBP 8711) and type strain of mushroom-associated actinobacterial species Mycetocola tolaasinivorans (MAFF $211325^{\mathrm{T}}$ ) as well as the reference strains of plant-pathogenic actinobacterial strains Clavibacter michiganensis subsp. michiganensis (ICMP 22049) (Osdaghi et al. 2018a) and Curtobacterium flaccumfaciens pv. flaccumfaciens (ICMP 22069) (Osdaghi et al. 2016) were used as controls in all of the phenotypic and biochemical experiments. All of the tests were repeated twice.

Pathogenicity tests. Pathogenicity and host range of the bacterial strains isolated in this study (Table 1) were evaluated on edible mushrooms. Reactions on vegetables and effects on mycelium of filamentous fungi were also evaluated. Three commercially grown edible mushroom species in Iran (i.e., button mushroom [A. bisporus 'A15'], king oyster mushroom [Pleurotus eryngii], and lingzhi mushroom [Ganoderma lucidum]) were used for pathogenicity and host range assays. Bacterial suspension was prepared from the freshly grown cells on YPGA medium $\left(1 \times 10^{5} \mathrm{CFU} / \mathrm{ml}\right.$ in SDW $)$ as described previously (Ansari et al. 2019a). Different inoculation

Table 1. Bacterial strains used in this study, their source and date of isolation, and the results of two differentiative phenotypic tests

\begin{tabular}{|c|c|c|c|c|c|c|c|}
\hline Strain & CFBPa code & Taxon & Source & Region & Date & $\begin{array}{c}\text { Hydrolysis of } \\
\text { Tween } 80^{b}\end{array}$ & $\begin{array}{l}\text { Fermentation of } \\
\text { melezitose }^{b}\end{array}$ \\
\hline Ir1146 & NA & Mycetocola sp. & Button mushroom & Tehran, Iran & 2018 & - & + \\
\hline Ir1162 & CFBP 8708 & Mycetocola sp. & Button mushroom & Alborz, Iran & 2018 & - & - \\
\hline Ir1169 & CFBP 8712 & Mycetocola sp. & Button mushroom & Alborz, Iran & 2018 & + & - \\
\hline Ir1170 & CFBP 8709 & Mycetocola $\mathrm{sp}$. & Button mushroom & Tehran, Iran & 2018 & - & - \\
\hline Ir1171 & NA & Mycetocola sp. & Button mushroom & Tehran, Iran & 2018 & - & - \\
\hline Ir1184 & NA & Mycetocola sp. & Button mushroom & Alborz, Iran & 2018 & - & - \\
\hline MAFF 211325 & NA & Mycetocola tolaasinivorans & Oyster mushroom & Japan & 1998 & - & - \\
\hline CFBP 8711 & CFBP 8711 & Pseudomonas reactans & Button mushroom & Fars, Iran & 2018 & ND & ND \\
\hline CFBP 8707 & CFBP 8707 & Pseudomonas tolaasii & Button mushroom & Fars, Iran & 2018 & ND & ND \\
\hline
\end{tabular}

a CFBP, International Center for Microbial Resources-French Collection for Plant-Associated Bacteria (IRHS UMR 1345 INRA-ACO-UA, 42 rue Georges Morel, 49070 Beaucouzé Cedex, France); NA, not assigned.

b ND, not determined; +, positive; -, negative. 
techniques were used to assess the pathogenicity of the bacterial strains on mushrooms. Freshly harvested mushroom caps were inoculated by spotting the bacterial suspension (four spots per cap and $20 \mu \mathrm{l}$ per spot) using a micropipette onto the intact surface of mushroom caps (Fig. 1A), a longitudinal section of mushroom cap and stipe (Fig. 1B), or a cut section of the caps as shown in Figure 1C. Furthermore, the mushroom caps were inoculated by spraying the same suspension using an A7 mini atomizer on both the intact cap bodies and the cut surface of the caps (Fig. 2B). Inoculated specimens were placed in a dark moist chamber at 24 to $27^{\circ} \mathrm{C}$ and periodically monitored for the appearance of disease symptoms up to $72 \mathrm{~h}$ postinoculation (hpi). Koch's postulates were completed by reisolating the inoculated strains on YPGA medium from all of the symptomatic caps. Confirmation of the reisolated bacterial strains was made by determining gram reaction and colony characteristics on YDC medium. Pathogenicity and host range tests were repeated three times. Additionally, reactions induced by the strains isolated in this study were evaluated on sliced discs of carrot (Daucus carota 'Nantesforto'), cucumber (Cucumis sativus 'Biet Alpha'), and potato in petri dishes as described previously (Mafakheri et al. 2017, 2019). In brief, fresh vegetables were surface sterilized with a $70 \%$ ethanol solution, rinsed three times in SDW, and cut into 5-mm-diameter discs. The discs (five discs per strain) were placed in sterile petri dishes on wet sterile filter paper and drop inoculated using $20 \mu \mathrm{l}$ (four drops per disc on the corners of an imaginary square) of the freshly prepared bacterial suspension as described above. Petri dishes were incubated in a dark moist chamber at 24 to $27^{\circ} \mathrm{C}$, and symptom development was monitored up to $72 \mathrm{hpi}$. The experiment was repeated twice. Lastly, to assess the effect of bacterial strains on the mycellium of filamentous fungi, we inoculated the bacterial suspension on the mycelium of Acremonium sp., Fusarium begonia, Fusarium brevicatenulatum, Fusarium circinatum, Fusarium equiseti, Fusarium foetens, Fusarium oxysporum, Fusarium proliferatum, Fusarium solani, and Phytopythium sp. grown on potato dextrose agar medium at 24 to $27^{\circ} \mathrm{C}$ for 2 weeks. All of the fungal species were provided by the Mycology Collection in the Department of Plant Protection, Shiraz University, Iran. In all of the experiments, controls were treated in the same manner using the standard strains of $P$. tolaasii (CFBP 8707) and $M$. tolaasinivorans (MAFF $211325^{\mathrm{T}}$ ), whereas the negative control was inoculated using SDW as described above. The experiment was repeated twice.

Tolaasin production/detoxification activity. To evaluate whether the bacterial strains isolated in this study could produce tolaasin or tolaasin-like compounds, we inoculated the freshly prepared bacterial suspension $\left(1 \times 10^{5} \mathrm{CFU} / \mathrm{ml}\right.$ in SDW $)$ onto potato tuber discs as described previously (Murata and Magae 1996; Shirata et al. 1995). Tolaasin activity on potato tuber discs leads to surface blackening in the presence of toxic effect, whereas the level of tolaasin toxicity could be semiquantitatively determined by the extent of blackening of the discs (Shirata et al. 1995; Tsukamoto et al. 1998). To confirm the results of the potato tuber discs test, the experiment, known as the "white line test," was also conducted on KB medium (Wong and Preece 1979). For this aim, tolaasin production in the six atypical strains isolated in this study was evaluated by coculturing these strains with $P$. reactans strain CFBP 8711 and observing the presence or absence of a white line inside the culture medium between the test strains and $P$. reactans using the procedure described by Wong and Preece (1979). The white line is the result of an interaction between tolaasin produced by $P$. tolaasii and a substance called white line-inducing principle (WLIP) produced by $P$. reactans (Rainey et al. 1992; Wong and Preece 1979). A tolaasin-producing strain of $P$. tolaasii (CFBP 8707) was used as a positive control, whereas the actinobacterial plant pathogen Clavibacter michiganensis subsp. michiganensis (ICMP 22049) was used as a negative control.

To further confirm whether tolaasin biosynthesize gene (AF291753.1) (Lee and Cha 1998) was present in the bacterial strains isolated in this study, they were screened using the primer pair Pt-1A/Pt-1D1

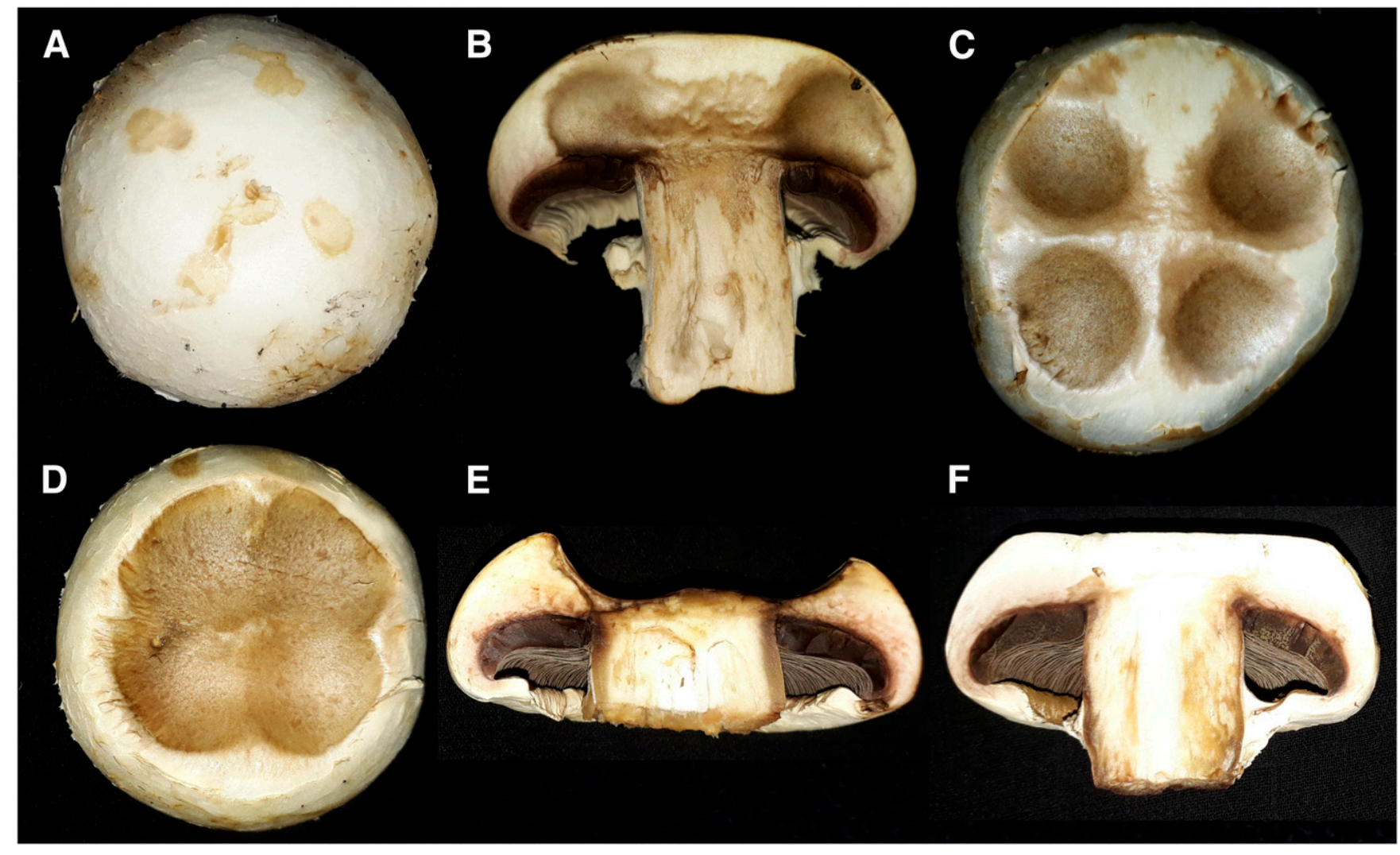

Fig. 1. Symptoms of bacterial brown pit disease on button mushroom caps artificially inoculated with Mycetocola sp. strains isolated in this study. A, Drop inoculation of Mycetocola sp. strains on the intact surface of mushroom cap led to the development of deep yellow to pale brown spots in the site of inoculation, whereas $B$ to $D$, brownish pitted areas were observed when the cut cap was inoculated. E, Cross-section from the inoculated mushroom caps revealed the progression of pitted areas into the flesh tissues. F, Mushroom caps inoculated with sterile distilled water remained healthy. 
(Table 2) (Lee et al. 2002). DNA extraction was carried out using the Expin Combo GP (GeneAll) DNA extraction kit as recommended by the manufacturer. The quality and quantity of DNAs were spectrophotometrically evaluated and adjusted to $50 \mathrm{ng} / \mu \mathrm{l}$ using Nanodrop ND-100 (Nanodrop Technologies) for further uses. PCRs were performed using the procedure as described previously (Osdaghi et al. 2018c). In brief, the Universal PCR Kit-Ampliqon Taq DNA Polymerase Master Mix Red (Ampliqon A/S)—was applied according to the manufacturer's recommendations. For each strain, a 50- $\mu$ l PCR reaction, including $100 \mathrm{ng}$ of total DNA and $2 \mu \mathrm{l}$ of each primer $(10 \mathrm{pmol} / \mu \mathrm{l})$, was used. The sequences of the corresponding primers and annealing temperatures are described in Table 2. In all of the PCR tests, standard strains of $P$. tolaasii (CFBP 8707 ) and $P$. reactans (CFBP 8711) were used as positive and negative controls, respectively. To evaluate the putative tolaasin detoxification activity, all of the six bacterial strains isolated in this study were coinoculated with $P$. tolaasii on the mushroom caps and potato tuber discs to assess the antagonistic/synergistic effect of the bacterial strains on each other. For this aim, $200 \mu \mathrm{l}$ of a $1 \times 10^{5}-\mathrm{CFU} / \mathrm{ml}$ suspension of $P$. tolaasii (CFBP 8707) was separately mixed with 200- $\mu$ l cell suspension of each of the six bacterial strains (with the same concentration) and coinoculated on mushroom caps and potato tuber discs using the procedure as described above. Negative controls were inoculated with the mixed suspension of $P$. tolaasii and Clavibacter michiganensis subsp. michiganensis (ICMP 22049), whereas the positive control was inoculated with the mixed suspensions of P. tolaasii (CFBP 8707) and the tolaasin-detoxifying strain of M. tolaasinivorans (MAFF $211325^{\mathrm{T}}$ ) using the procedure as described above. The experiments were repeated twice.

Phylogenetic analyses. Although morphological features and phenotypic characteristics suggested that the atypical bacterial strains isolated in this study belong to the family Microbacteriaceae (Actinobacteria), we could not assign a taxonomic status to the strains in a genus level. Hence, to decipher the phylogenetic position of the strains, 16S rRNA was sequenced using the fD1/rP2 primer pair (Table 2) as described by Weisburg et al. (1991). PCR parameters were the same as described above. The PCR products were sent to Bioneer Corporation (http://www.Bioneer.com; Daejeon, South Korea) to be sequenced via Sanger sequencing technology. Resulting sequences were analyzed with the BLASTn program (https:// blast.ncbi.nlm.nih.gov/Blast.cgi) and phylogenetically compared with those of almost all genera/species of Microbacteriaceae (Evtushenko and Takeuchi 2006). BLASTn results suggested that the six strains isolated from mushroom caps were closely related to the actinobacterial genus Mycetocola spp. (Microbacteriaceae). To further refine the phylogenetic position of the bacterial strains, they were subjected to MLSA using the sequences of six housekeeping genes (i.e., atpD, dnaK, gyrB, ppK, recA, and rpoB) as recommended for the Microbacteriaceae members (Jacques et al. 2012; Osdaghi et al. 2018b). Specific primer pairs were designed for the amplification of DNA fragments in all of the six housekeeping genes based on the available genome sequences of Mycetocola strains (i.e., GenBank accession numbers CP026949, FOVM01000000, FUKR01000000, RCUV01000000, RCUW01000000, RCUX01000000, RCUY01000000, and RCWJ01000000) according to Jacques et al. (2012). PCR parameters and sequencing procedures were the same as described above, whereas the sequences of the primer pairs are shown in Table 2. Resulting sequences were analyzed using the BLASTn program, and the corresponding sequences in a set of 23 actinobacterial strains that showed the highest similarity $(>85 \%)$ to the sequences obtained in this study and all of the type strains of the Mycetocola species, including Mycetocola lacteus (Tsukamoto et al. 2001)

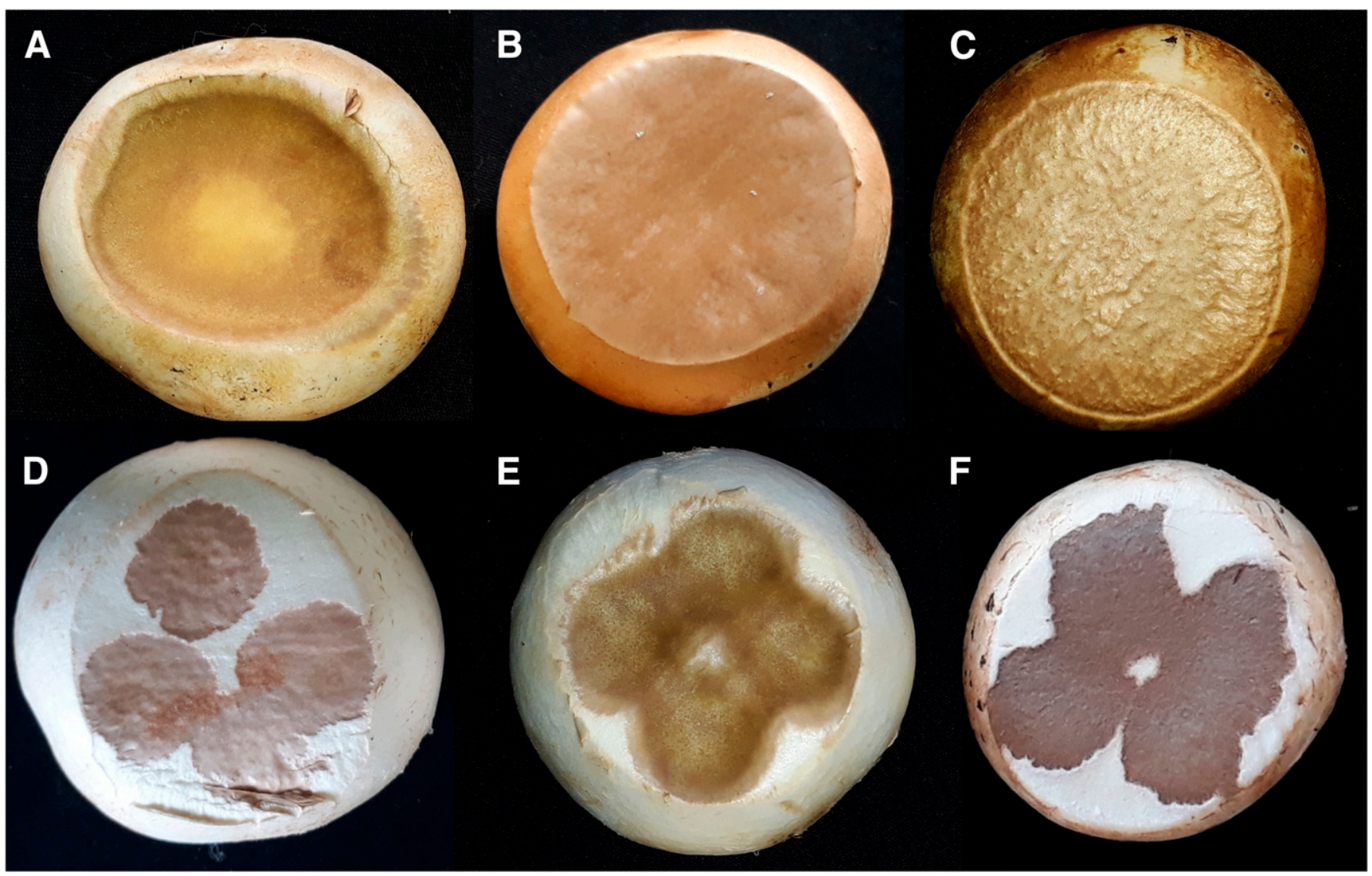

Fig. 2. A and B, Individual inoculation and $\mathbf{C}$ to $\mathrm{E}$, coinoculation of Mycetocola sp. strains isolated in this study and Pseudomonas tolaasii (CFBP 8707) on button mushroom caps Mycetocola sp. strains induced brown pit symptoms (A, strain Ir1146), whereas P. tolaasii induced brown blotch symptoms (B and F, strain CFBP 8707) on button mushroom caps. C, Coinoculation of the two pathogens on the same cap led to the simultaneous development of both brown pit and blotch symptoms (Ir1170 + CFBP 8707 ), although variability in pitting severity was observed among the Mycetocola sp. strains when coinoculated with $P$. tolaasii. D, Coinoculation of Ir1171 with $P$. tolaasii led to the development of deep brown discoloration with weakly pitting patterns, whereas $\mathrm{E}$, coinoculation of Ir1146 with $P$. tolaasii led to the development of brown pit areas. 
(JCM11654T), Mycetocola manganoxydans (Luo et al. 2012) (CCTCC AB209002T), Mycetocola miduiensis (Zhu et al. 2013) (CGMCC 1.11101T), Mycetocola reblochoni (Bora et al. 2008) (JCM30549T), M. tolaasinivorans (Tsukamoto et al. 2001) (IF016277T), and Mycetocola zhadangensis (Shen et al. 2013) (ZD1-4T), were retrieved from the NCBI GenBank database and subjected to the phylogenetic analyses. However, we did not have access to the sequences of the six genes in Mycetocola saprophilus (Tsukamoto et al. 2001), because there was no publicly available genome sequence from this species until the date of submission of this manuscript. The sequences of individual gene fragments were concatenated following the alphabetic order of the genes, ending in a sequence of $4,450 \mathrm{bp}$ : nucleotides 1 to 870 for atpD, nucleotides 871 to 1,436 for dnaK (566 bp), nucleotides 1,437 to 1,982 for gyrB (546 bp), nucleotides 1,983 to 2,831 for ppk (849 bp), nucleotides 2,832 to 3,343 for recA (512 bp), and nucleotides 3,344 to 4,450 for $\mathrm{rpoB}(1,107 \mathrm{bp})$ genes. Phylogenetic trees were constructed from the concatenated sequences using the maximum likelihood method with MEGA7 software (Kumar et al. 2016). The model of evolution for maximum likelihood analysis was determined using the Modeltest tab in MEGA7. Clavibacter michiganensis subsp. michiganensis (NCPPB 382T) was used to root the phylogenetic tree with bootstrapping (1,000 replications). Pairwise and average genetic distances among different phylogenetic clades were also determined using MEGA7. To visualize the relationships between DNA sequences of six strains isolated from mushroom with the remaining actinobacterial strains isolated from different sources, NeighborNet network was constructed using SplitsTree version 4.14.4 as described by Huson and Bryant (2006).

GenBank accession numbers and strain availability. The sequenced nucleotides were deposited into the GenBank database under the following accession numbers: MN294693 to MN294698 for 16S rRNA, MN327992 to MN327997 for atpD, MN327998 to MN328003 for dnaK, MN328004 to MN328009 for $g y r B, ~ M N 328010$ to $\mathrm{MN} 328015$ for $p p K, \mathrm{MN} 328016$ to $\mathrm{MN} 328021$ for $r e c A$, and MN328022 to MN328027 for rpoB. Furthermore, a pure culture of the representative strains isolated in this study was deposited in the International Center for Microbial Resources-French Collection for Plant-Associated Bacteria culture collection and assigned accession numbers as follows: Ir1162 = CFBP 8708, Ir1169 = CFBP 8712, and $\operatorname{Ir} 1170=$ CFBP 8709 .

\section{Results}

Bacterial strains. From September to December 2018, six bacterial strains-designated Ir1146, Ir1162 = CFBP 8708, Ir1169 = CFBP 8712, Ir1170 = CFBP 8709, Ir1171, and Ir1184 (Table 1) were isolated from symptomatic button mushroom caps grown in commercial farms in Alborz and Tehran provinces in central Iran.
Symptomatic mushrooms had pale brown spots on the cap surface resembling the symptoms described for bacterial blotch in the literature. In all of the cases, intensity of the symptoms in the mushroom caps from which the six bacterial strains were isolated was less severe (in terms of tissue discoloration) than that of the caps infected with $P$. tolaasii and/or other pseudomonad species (data not shown). The six bacterial strains were gram positive, possessing circular, slightly convex, smooth, nonfluorescent, and shiny colonies with whole margins. Bacterial colonies were slow growing on all of the tested culture media, reaching only 1 to $2 \mathrm{~mm}$ in diameter 72 to $96 \mathrm{hpi}$, whereas colony color differed slightly depending on the culture medium (Supplementary Fig. S1). For instance, on KB and YPGA media, creamy white colonies with opaque appearance were observed (Supplementary Fig. S1A and D), whereas the colonies were shiny and smaller in size on NA medium in the same timeframe (Supplementary Fig. S1B). On YDC medium, white shiny colonies were observed that were larger in size ( $2 \mathrm{~mm}$ in diameter) in comparison with those observed on the three remaining culture media (Supplementary Fig. S1C). The strains were oxidase negative, catalase positive, and obligate aerobic, and they were able to grow on TTC medium. All of the strains were negative in citrate utilization and levan production, whereas they were positive in arginine dihydrolase. The strains were negative in the fermentation of melezitose, except for Ir1146. Furthermore, all of the strains but Ir1169 were negative in the hydrolysis of Tween 80 (Table 1). The strains were also negative for HR on tobacco leaves and potato soft rot test. Based on the morphological characteristics and phenotypic features, the strains were identified as members of Microbacteriaceae (Actinobacteria).

Pathogenicity and host range. All of the six bacterial strains were faintly pathogenic on the intact surface of mushroom caps when either sprayed or spot inoculated on button mushroom. Deep yellow to pale brown areas were observed on the site of inoculation, but no deformed, blotched, and necrotic areas were observed (Fig. 1A). However, the strains were aggressively pathogenic when drop inoculated on the cut surface of mushroom cap or stipe, leading to brownish pitted areas on the site of inoculation 48 hpi (Fig. 1B to D). The most severe symptoms were observed when the bacterial suspension was drop inoculated onto the cut surface of the upper cap as shown in Figure 1C. Pitted areas 5 to $7 \mathrm{~mm}$ in diameter with the same size and shape of the inoculum drop were observed on the site of inoculation, whereas the surrounding areas remained asymptomatic. When the bacterial suspension was spread onto the total cut surface of the caps, pitted areas were observed all over of the inoculated cap surface 48 hpi (Fig. 1D). Cross-section from the inoculated mushroom caps revealed the pattern of symptom development, which included the progression of pitted areas into the flesh tissues of the cap up to $5 \mathrm{~mm}$ in depth as shown in Figure 1E. Although the intensity of cap discoloration was similar in all of the evaluated

Table 2. Primer pairs used in this study

\begin{tabular}{|c|c|c|c|c|c|}
\hline Primer name & $5^{\prime}-3^{\prime}$ Sequence & Target (gene) & $\begin{array}{c}\text { Size of } \\
\text { amplicon (bp) }\end{array}$ & $\begin{array}{c}\text { Annealing } \\
\text { temperature }\left({ }^{\circ} \mathrm{C}\right)\end{array}$ & Reference \\
\hline $\mathrm{fD} 1$ & AGAGTTTGATCCTGGCTCAG & $16 \mathrm{~S}$ ribosomal RNA & 1,484 & 63 & Weisburg et al. (1991) \\
\hline rP2 & ACGGCTACCTTGTTACGACTT & & & & \\
\hline atpDMyF & GTCGAGGTCAGCGGGTCGAT & $\operatorname{atpD}$ & 1,000 & 62 & This study \\
\hline atpDMyR & ACATCGAGTTYCCGCACGA & & & & \\
\hline dnaKMyF & GACGTCNTCGGGSAGCTTGTC & dnaK & 1,022 & 64 & This study \\
\hline dnaKMyR & CCGGKGACAACCGCCTCGG & & & & \\
\hline gyrBMyF & CACGCYGGMGGWAAGTTCGG & gyrB & 1,001 & 63 & This study \\
\hline gyrBMyR & GACTGGCARTCCTTGAGCTT & & & & \\
\hline ppKMyF & GCAGATGCTGCCGCGCTTC & $p p K$ & 978 & 60 & This study \\
\hline ppKMyR & CGCTTGAACTTCTTCTCGAT & & & & \\
\hline recAMyF & GCDCTCGCSCAGATCGACCG & recA & 848 & 63 & This study \\
\hline recAMyR & CCSTCGTAGGTGTACCAGG & & & & \\
\hline rpoBMyF & TGCGCGCAACGCATCCACCA & $r p o B$ & 1,217 & 64 & This study \\
\hline rpoBMyR & GCACGTTGATCAGGGTCTGC & & & & \\
\hline Pt-1A & ATCCCTTCGGCGTTTACCTG & Tolaasin & 448 & 58 & Lee et al. (2002) \\
\hline Pt-1D1 & CAAAGTAACCCTGCTTCTGC & & & & \\
\hline
\end{tabular}


bacterial strains, slight differences were observed in the pitting severity among the strains. For instance, the strain Ir1146 showed the most severe aggressiveness (in terms of the depth of pitted areas), whereas the strain Ir1184 showed a relatively less severe pitting pattern. Spray inoculation of the mushroom caps with the bacterial suspension caused the same symptomology on the caps. Only slight discoloration was observed when the intact surfaces of mushroom caps were treated with the bacterial strains, whereas spraying the bacterial suspension on cut surfaces of the caps resulted in a large cavity in the caps as shown in Figure 2A. However, mushroom caps inoculated with $P$. tolaasii showed deep brown discoloration with no malformation on the cut surface of the caps (Fig. 2B). All of the control caps treated with SDW remained healthy up to $72 \mathrm{hpi}$ (Fig. 1F).

Interestingly, coinoculation of the gram-positive and $P$. tolaasii strains on the same cap led to the simultaneous development of both blotching and pitting symptoms on the cap surface, indicating that the two strains were possessing synergistic or additive effects on one another, whereas the gram-positive strains could not suppress the pathogenicity of P. tolaasii (Fig. 2C). However, different patterns of symptom development were observed when each of the six grampositive strains was coinoculated with $P$. tolaasii on mushroom caps. For instance, coinoculation of Ir1169, Ir1170, and Ir1171 with P. tolaasii led to the development of deep brown discoloration with weakly pitting pattern (Fig. 2D), whereas coinoculation of Ir1146, Ir1162, and Ir1184 with P. tolaasii led to the development of brown pit areas similar to those observed in the lone inoculation of the grampositive bacterial strains (Fig. 2E). Mushroom caps that were drop inoculated only with $P$. tolaasii strain CFBP 8707 showed deep brown and blotched areas on the site of inoculation 24 hpi (Fig. 2F).

Furthermore, all of the six bacterial strains as well as $P$. tolaasii were pathogenic on king oyster mushroom $(P$. eryngii), and induced brownish pitting symptoms on the cut surface of the mushroom, although the depth of the pitted areas and the intensity of discoloration were less severe in comparison with those observed in button mushroom. However, neither the gram-positive strains nor $P$. tolaasii and M. tolaasinivorans were pathogenic on lingzhi mushroom (G. luci$d u m)$. The six strains isolated in this study did not induce any reactions on potato tuber, carrot root, and cucumber fruit discs inoculated with the same bacterial suspension used for the inoculation of cut cap, whereas $P$. tolaasii induced brownish black spots on the inoculated discs of all of the vegetable species. Furthermore, none of the six gram-positive bacterial strains, P. tolaasii, and M. tolaasinivorans affected the mycelium mass of the evaluated fungal species.

Tolaasin production. We did not find evidence for tolaasin production/activity in the bacterial strains isolated in this study using any of the standard techniques described in the literature. Negative reactions on vegetables (i.e., carrot, cucumber, and potato) are described above. Also, when the bacterial strains isolated in this study were streaked side by side with $P$. tolaasii and $P$. reactans on KB medium, they did not induce "white lines" in the culture medium, although the $P$. tolaasii strain CFBP 8707 (positive control) did as expected. This was the indication of the fact that neither tolaasin nor WLIP could be produced by the gram-positive bacterial strains isolated in this study. Additionally, in PCR-based screening of the bacterial strains for the presence of tolaasin biosynthesize gene sequence using the primer pair Pt-1A/Pt-1D1, the expected 448-bp DNA fragment was not amplified in the bacterial strains isolated in this study. However, the same primer pair directed the amplification of a 448-bp tolaasin biosynthesize gene fragment in the $P$. tolaasii strain, confirming the biosynthesis of the toxin in this species.

Tolaasin detoxification activity. Coinoculation of the bacterial strains isolated in this study on potato tuber discs and mushroom caps along with $P$. tolaasii led to the development of disease symptoms as seen in the $P$. tolaasii-alone treatment, indicating that the grampositive bacterial strains did not have tolaasin detoxification activity on the discs and mushroom caps.

Phylogenetic analyses. BLASTn search using a 720-bp DNA fragment of $16 \mathrm{~S}$ rRNA revealed that all of the six bacterial strains isolated in this study had the highest sequence similarity (99 to 100\%) to the mushroom-associated Mycetocola spp. strains. The maximum likelihood phylogenetic tree constructed using the 16S rRNA sequences of representative actinobacterial strains revealed that all of the six strains were clustered in the same clade with the mushroomassociated Mycetocola spp. strains (i.e., the type strains of M. saprophilus, M. tolaasinivorans, and M. lacteus) (Supplementary Fig. S2). Furthermore, BLASTn analyses using the individual sequences of six housekeeping genes (i.e., atpD, dnaK, gyrB, ppK, recA, and $\mathrm{rpoB}$ ) were consistent with the finding that the six strains described here were members of Mycetocola spp. The phylogenetic tree constructed using the concatenated sequences of six housekeeping genes in the Mycetocola sp. strains isolated in this study along with 23 actinobacterial strains - retrieved from the GenBank database-revealed that the strains Ir1146, Ir1162, Ir1169, Ir1170, Ir1171, and Ir1184 were clustered in a monophyletic clade close to the type strains of M. tolaasinivorans (IF016277T) and M. lacteus (JCM11654T) but were differentiated from the other nonmushroom-associated Mycetocola spp. strains as shown in Figure 3. Indeed, all of the Mycetocola spp. strains that were included in this study were divided into three standalone phylogenetic clades designated as clades I, II, and III (Fig. 3). Six mushroom-pathogenic strains isolated in this study as well as the mushroom-associated but nonpathogenic species $M$. tolaasinivorans and $M$. lacteus were designated as clade I, whereas clade II included $M$. reblochoni, and clade III included $M$. manganoxydans, M. miduiensis, and M. zhadangensis (Fig. 3). We did not have access to the sequences of the six housekeeping genes in $M$. saprophilus; hence, the phylogenetic relationship between the strains isolated in this study and the nonpathogenic species $M$. saprophilus remains undetermined. Clades I and II of Mycetocola spp. were shown to be monophyletic, whereas clade III was clustered apart from clades I and II and placed in a monophyletic group along with Cryobacterium sp. and Microterricola sp. Mushroompathogenic Mycetocola sp. strains isolated in this study were not phylogenetically close to any of the actinobacterial plant-pathogenic species, including Clavibacter michiganensis, Curtobacterium flaccumfaciens, Leifsonia xyli, Rathayibacter rathayi, and Rathayibacter tritici (Fig. 3).

Furthermore, the phylogenetic network was generated using the NeighborNet method implemented in SplitsTree version 4.14.4 for the concatenated dataset of sequences (Fig. 4). The NeighborNet network was in congruence with the maximum likelihood phylogenetic tree, where all of the strains isolated in this study were clustered in a monophyletic clade (clade I) along with the type strains of M. lacteus and M. tolaasinivorans. The Mycetocola spp. strains, which were designated as clades II and III in maximum likelihood phylogenetic tree, were clustered in separate clades (II and III) in the NeighborNet network as well. High genetic diversity and sequence variation were observed among the Mycetocola sp. strains isolated in this study, and none of the six strains shared the same multilocus haplotype with one another. The pairwise genetic distance among the strains isolated in this study using the concatenated sequences of six housekeeping genes ranged between 0.0003 and 0.0136 , whereas the average distance among the six strains was 0.0068 . Furthermore, the average pairwise distances between the strains isolated in this study and M. lacteus or M. tolaasinivorans were 0.0225 and 0.0449 , respectively, whereas the distance between the type strains of M. lacteus JCM11654T and M. tolaasinivorans IF016277T was calculated as 0.0303 . Taken together, phylogenetically heterogeneous strains were published as Mycetocola spp. in the literature (as surrounded by a red box in Fig. 4). Hence, further complete genome sequence-based molecular-phylogenetic analyses are needed to elucidate the taxonomic status of the strains nominated as Mycetocola spp.

\section{Discussion}

In this study, we describe a novel bacterial disease on artificially inoculated edible mushrooms caused by Mycetocola sp. and nominate the new disease as bacterial brown pit based on the brown discoloration and cavity symptoms on the infected mushroom caps. Pitting symptoms have not been observed on naturally infected 
mushroom caps in mushroom farms; instead, natural symptoms of the disease were similar to those of brown blotch diseases (Osdaghi et al. 2019). It is more likely that the bacterial brown pit will be referred to as a member of the complex of bacterial blotch diseases because natural symptoms of the new disease were apparently similar to those of brown blotch disease caused by different pseudomonads (e.g., $P$. tolaasii). Indeed, considering the results of this project in a larger scale (Hamidizade 2019), other than the 6 Mycetocola sp. strains, we have isolated 27 P. tolaasii, 20 P. reactans, and 40 taxonomically undetermined Pseudomonas spp. strains from the symptomatic mushrooms in Iran. However, artificial inoculation of cut mushroom caps revealed a different symptomology caused by the

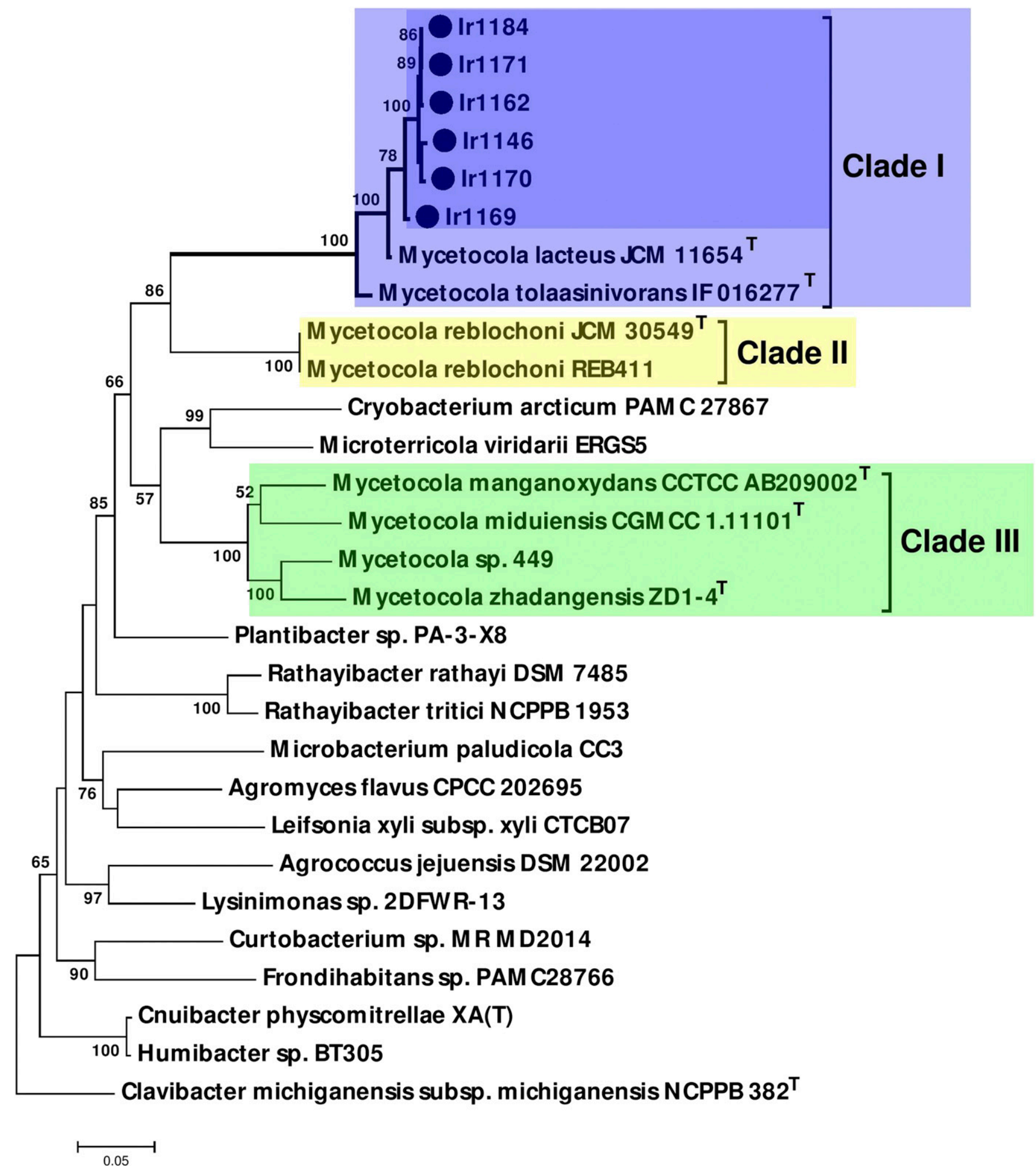

Fig. 3. Phylogeny of Mycetocola sp. strains isolated in this study among the members of the Microbacteriaceae family based on the concatenated sequences of six housekeeping genes (i.e., atpD, dnaK, gyrB, ppK, recA, and rpoB). Clavibacter michiganensis subsp. michiganensis was used as an outgroup to root the tree. The bar presents numbers of substitutions per site. Different background highlights indicate different phylogenetic clades within the Mycetocola sp. strains. All of the clade I strains were isolated from edible mushrooms, whereas clades II and III strains were isolated from various ecological niches. Although all of the mushroom-associated strains were clustered in a monophyletic clade, mushroom-pathogenic strains isolated in this study (indicated by deep blue highlight) were clustered distinct from the mushroom-associated nonpathogenic strains. 
Mycetocola sp. strains, which included pitting on the flesh of cut caps (Fig. 1). Inoculation of the intact cap surface of button mushroom did not induce the pitting symptoms, suggesting the role of external cap layers in the suppression of the pathogenicity of Mycetocola sp. This is the first description of a mushroom disease caused by a grampositive bacterium in the family Microbacteriaceae, Actinobacteria (Stackebrandt et al. 1997).

The genus Mycetocola spp. was described for the first time by Tsukamoto et al. (2001) to encompass tolaasin-detoxifying bacterial strains isolated from fruiting bodies of cultivated oyster mushroom (P. ostreatus) in Japan. At that time, 10 strains isolated from mushroom bodies were assigned into three standalone species (i.e., $M$. tolaasinivorans [MAFF 211325T], M. lacteus [MAFF 211326T], and M. saprophilus [MAFF 211324T]) (Tsukamoto et al. 2001). Species assignment was based on phenotypic characteristics of the strains as well as DNA-DNA hybridization values and the phylogeny of $16 \mathrm{~S}$ rRNA gene sequences (Tsukamoto et al. 2001). These species were reported to be saprophytic but not parasitic or pathogenic to edible mushrooms, and they were capable of detoxifying tolaasin and suppressing the development of brown blotch disease on mushroom caps (Tsukamoto et al. 1998). In the subsequent years, a number of new species isolated from various ecological niches were assigned into the genus based on the phylogeny of 16S rRNA (Bora et al. 2008; Luo et al. 2012; Shen et al. 2013). However, MLSA data obtained in this study challenge traditional taxonomy of the genus, where three standalone phylogenetic clades were observed among different species of the genus (Figs. 3 and 4). Phylogenetic differences of the three Mycetocola spp. clades are also reflected in their source of isolation. In this regard, all clade I strains were isolated from edible mushrooms, whereas the clade II strains were isolated from Reblochon cheese, and clade III strains were isolated from extreme environments (i.e., desert and glacier) (Bora et al. 2008; Luo et al. 2012; Shen et al. 2013). All of these lines of evidence bring us to the conclusion that current taxonomy of actinobacterial strains designated as Mycetocola spp. does not reflect their correct phylogenetic position.
Hence, a formal taxonomic study encompassing all of the representative strains of Mycetocola spp. is warranted to elucidate the taxonomic position of the strains and assign appropriate epithet for the suspected novel taxa.

Interestingly, none of the strains isolated in this study showed tolaasin detoxification activity when they were coinoculated along with $P$. tolaasii onto button mushroom caps and potato tuber discs. Instead, all of the strains were highly pathogenic on both damaged button mushroom and king oyster mushroom, and unlike $P$. tolaasii, they did not induce blackening on potato tuber discs. Furthermore, comparison of the strains isolated in this study with those of previously described mushroom-associated Mycetocola species in terms of pathogenicity and tolaasin-detoxification suggests different evolutionary scenarios in each of the two groups of bacteria (Tsukamoto et al. 1998). Further comparisons in vitro and in situ are warranted to clearly describe the ecology of these organisms in commercial mushroom production. Although all of the mushroom-associated Mycetocola spp. strains-regardless of their pathogenic and tolaasin-detoxifying nature-were clustered in a monophyletic clade (clade I in Figs. 3 and 4), taxonomic allocation of the pathogenic strains in the species level needs further investigations. This was in part because of the fact that the sequences of six housekeeping genes in $M$. saprophilus were lacking in the public databases, preventing us from reaching a decisive conclusion on the taxonomic position of the strains isolated in this study. Furthermore, genetic distances among the strains isolated in this study and the tolaasin detoxification Mycetocola spp. strains (as described above) did not provide sufficient support to assign a species status to our strains. Additionally, detached positions of the six strains in the phylogenetic tree (Fig. 3) raise the speculation that the pathogenic strains could belong to a new species within the genus.

In summary, we describe a new pathogen of edible mushrooms different from all bacterial pathogens of mushrooms (cultivated or wild) described before. These results significantly increased the breadth of organisms causing bacterial diseases of edible mushrooms

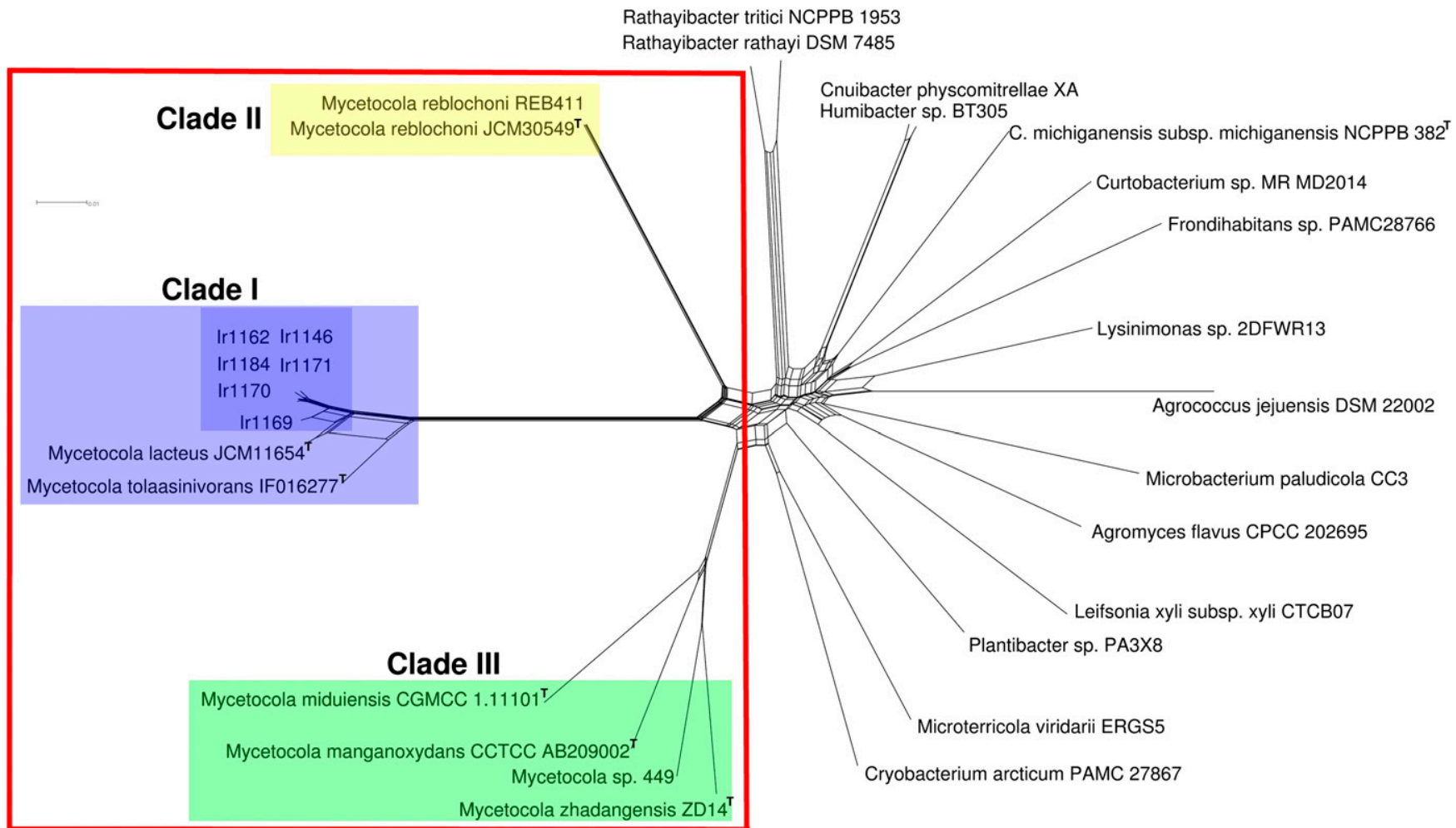

Fig. 4. NeighborNet network generated from the concatenated sequences of six housekeeping genes (i.e., atpD, dnaK, gyrB, ppK, recA, and rpoB) in the Mycetocola sp. strains isolated in this study along with the members of Microbacteriaceae family constructed using the SplitsTree version 4.14.4. The network confirms division of the Mycetocola sp. strains into three separate clades-as indicated by different background highlights-based on their source of isolation. All of the mushroom-associated strains were clustered in clade I as a monophyletic group. 
and underline the potential threats owing to new disease outbreaks by the newly emerging pathogens. Although the incidence, distribution, and economic importance of the Mycetocola sp. pathogen have yet to be determined, considering the high revenue of the mushroom industry in Iran, more strict inspections and surveys are recommended to limit the risk of crop losses because of the bacterial brown pit pathogen infection. Depending on future surveys, a comprehensive breeding program may need to take into account a wider array of pathogens, including this Mycetocola sp.

\section{Acknowledgments}

We appreciate Dr. Ebrahim Mohammadi Goltapeh and Khadijeh Marzani (both from Tarbiat Modares University, Tehran) as well as Abbas Niknahad for their support during surveys and sampling in commercial mushroom farms.

\section{Literature Cited}

Ansari, M., Taghavi, S. M., Hamzehzarghani, H., Valenzuela, M., Siri, M. I., and Osdaghi, E. 2019a. Multiple introductions of tomato pathogen Clavibacter michiganensis subsp. michiganensis into Iran as revealed by a global-scale phylogeographic analysis. Appl. Environ. Microbiol. 85:e02098-19.

Ansari, M., Taghavi, S. M., Zarei, S., Mehrb-Moghadam, S., Mafakheri, H., Hamidizade, M., and Osdaghi, E. 2019b. Phenotypically and genotypically heterogeneous strains of Pseudomonas syringae associated with alfalfa leaf spot disease in Iran. Plant Dis. 103:3199-3208.

Błaszczyk, L., Siwulski, M., Sobieralski, K., and Frużyńska-Jóźwiak, D. 2013. Diversity of Trichoderma spp. causing Pleurotus green mould diseases in Central Europe. Folia Microbiol. (Praha) 58:325-333.

Bora, N., Vancanneyt, M., Gelsomino, R., Snauwaert, C., Swings, J., Jones, A. L., and Goodfellow, M. 2008. Mycetocola reblochoni sp. nov., isolated from the surface microbial flora of Reblochon cheese. Int. J. Syst. Evol. Microbiol. 58: 2687-2693.

Chowdhury, P. R., Pay, J., and Braithwaite, M. 2007. Isolation, identification and ecology of Ewingella americana (the causal agent of internal stipe necrosis) from cultivated mushrooms in New Zealand. Australas. Plant Pathol. 36: 424-428.

Collins, M. D., and Jones, D. 1983. Reclassification of Corynebacterium flaccumfaciens, Corynebacterium betae, Corynebacterium oortii and Corynebacterium poinsettiae in the genus Curtobacterium as Curtobacterium flaccumfaciens comb. nov. Microbiol. 129:3545-3548.

Davis, M. J., Gillaspie, A. G., Jr., Vidaver, A. K., and Harris, R. W. 1984. Clavibacter: A new genus containing some phytopathogenic coryneform bacteria, including Clavibacter xyli subsp. xyli sp. nov., subsp. nov., and Clavibacter xyli subsp. ncynodontis subsp. nov., pathogens that cause ratoon stunting disease of sugarcane and bermudagrass stunting disease. Int. J. Syst. Bacteriol. 34:107-117.

Eastwood, D., Green, J., Grogan, H., and Burton, K. 2015. Viral agents causing brown cap mushroom disease of Agaricus bisporus. Appl. Environ. Microbiol. 81:7125-7134.

Evtushenko, L. I., Dorofeeva, L. V., Subbotin, S. A., Cole, J. R., and Tiedje, J. M. 2000. Leifsonia poae gen. nov., sp. nov., isolated from nematode galls on Poa annua, and reclassification of 'Corynebacterium aquaticum' Leifson 1962 as Leifsonia aquatica (ex Leifson 1962) gen. nov., nom. rev., comb. nov. and Clavibacter xyli Davis et al. 1984. with two subspecies as Leifsonia xyli (Davis et al. 1984) gen. nov., comb. nov. Int. J. Syst. Evol. Microbiol. 50:371-380.

Evtushenko, L. I., and Takeuchi, M. 2006. The family Microbacteriaceae. Pages 1020-1098 in: The Prokaryotes. M. Dworkin, S. Falkow, E. Rosenberg, K. H. Schleifer, and E. Stackebrandt, eds. Springer, New York, NY

FAOSTAT. 2018. The Agriculture Production Domain. http://www.fao.org/ faostat/en/?\#compare

Fletcher, J. T., and Gaze, R. H. 2007. Mushroom Pest and Disease Control: A Colour Handbook. CRC Press, Boca Raton, FL.

Godfrey, S. A., Harrow, S. A., Marshall, J. W., and Klena, J. D. 2001. Characterization by $16 \mathrm{~S}$ rRNA sequence analysis of pseudomonads causing blotch disease of cultivated Agaricus bisporus. Appl. Environ. Microbiol. 67: 4316-4323.

Grogan, H. M. 2006. Fungicide control of mushroom cobweb disease caused by Cladobotryum strains with different benzimidazole resistance profiles. Pest Manag. Sci. 62:153-161.

Hamidizade, M. 2019. Feasibility of biocontrol of bacterial brown blotch of button mushroom (Agaricus bisporus) using antagonistic bacteria. Master of Science thesis. Department of Plant Protection, Shiraz University, Shiraz, Iran.

Huson, D. H., and Bryant, D. 2006. Application of phylogenetic networks in evolutionary studies. Mol. Biol. Evol. 23:254-267.

Iacobellis, N. S., and Lo Cantore, P. 2003. Pseudomonas 'reactans' a new pathogen of cultivated mushrooms. Pages 595-605 in: Pseudomonas syringae Pathovars and Related Pathogens. N. S. Iacobellis, A. Collmer, S. W. Hutcheson, J. W. Mansfield, C. E. Morris, J. Murillo, N. W. Schaad, D. E. Stead, G. Surico, and M. S. Ullrich, eds. Kluwer Academic Publishers, Dordrecht, The Netherlands.
Jacques, M. A., Durand, K., Orgeur, G., Balidas, S., Fricot, C., Bonneau, S., Quillévéré, A., Audusseau, C., Olivier, V., Grimault, V., and Mathis, R. 2012. Phylogenetic analysis and polyphasic characterization of Clavibacter michiganensis strains isolated from tomato seeds reveal that nonpathogenic strains are distinct from C. michiganensis subsp. michiganensis. Appl. Environ. Microbiol. 78:8388-8402.

King, E. O., Ward, M. K., and Raney, E. E. 1954. Two simple media for the demonstration of pyocyanin and fluorescein. J. Lab. Clin. Med. 44:301

Kumar, S., Stecher, G., and Tamura, K. 2016. MEGA7: Molecular Evolutionary Genetics Analysis version. 7.0 for bigger datasets. Mol. Biol. Evol. 33: 1870-1874.

Lee, H.-I., and Cha, J.-S. 1998. Cloning of a DNA fragment specific to Pseudomonas tolaasii causing bacterial brown blotch disease of oyster mushroom (Pleurotus ostreatus). Korean J. Plant Pathol. 14:177-183.

Lee, H. I., Jeong, K. S., and Cha, J. S. 2002. PCR assays for specific and sensitive detection of Pseudomonas tolaasii, the cause of brown blotch disease of mushrooms. Lett. Appl. Microbiol. 35:276-280.

Lelliott, R. A., Billing, E., and Hayward, A. C. 1966. A determinative scheme for the fluorescent plant pathogenic pseudomonads. J. Appl. Bacteriol. 29: $470-489$

Luo, X., Wang, J., Zeng, X. C., Wang, Y., Zhou, L., Nie, Y., Dai, J., and Fang, C. 2012. Mycetocola manganoxydans sp. nov., an actinobacterium isolated from the Taklamakan desert. Int. J. Syst. Evol. Microbiol. 62:2967-2970.

Mafakheri, H., Taghavi, S. M., Banihashemi, Z., Osdaghi, E., and Lamichhane, J. R. 2017. Pathogenicity, host range and phylogenetic position of Agrobacterium species associated with sugar beet crown gall outbreaks in Southern Iran. Eur. J. Plant Pathol. 147:721-730.

Mafakheri, H., Taghavi, S. M., Puławska, J., de Lajudie, P., Lassalle, F., and Osdaghi, E. 2019. Two novel genomospecies in the Agrobacterium tumefaciens species complex associated with rose crown gall. Phytopathology 109:1859-1868.

Munsch, P., Alatossava, T., Marttinen, N., Meyer, J. M., Christen, R., and Gardan, L. 2002. Pseudomonas costantinii sp. nov., another causal agent of brown blotch disease, isolated from cultivated mushroom sporophores in Finland. Int. J. Syst. Evol. Microbiol. 52:1973-1983.

Murata, H., and Magae, Y. 1996. Toxin production in a mushroom pathogenic bacterium, Pseudomonas tolaasii strain PT814 is activated by signals present in a host, Pleurotus ostreatus, and those accumulating in the medium in the course of bacterial growth. Pages 483-494 in: Mushroom Biology and Mushroom Products: Proceedings of the Second International Conference University Park, Pennsylvania June 9-12, 1996. D. J. Royse, ed. Pennsylvania State University Press, University Park, PA.

Nair, N. G., and Fahy, P. C. 1973. Toxin production by Pseudomonas tolaasii Paine. Aust. J. Biol. Sci. 26:509-512.

Nutkins, J. C., Mortishire-Smith, R. J., Packman, L. C., Brodey, C. L., Rainey, P. B., Johnstone, K., and Williams, D. H. 1991. Structure determination of tolaasin, an extracellular lipodepsipeptide produced by the mushroom pathogen, Pseudomonas tolaasii Paine. J. Am. Chem. Soc. 113:2621-2627.

Osdaghi, E., Ansari, M., Taghavi, S. M., Zarei, S., Koebnik, R., and Lamichhane, J. R. 2018a. Pathogenicity and phylogenetic analysis of Clavibacter michiganensis strains associated with tomato plants in Iran. Plant Pathol. 67: 957-970.

Osdaghi, E., Martins, S. J., Sepulveda, L., Vieira, F. R., Pecchia, J. A., Beyer D. M., Bell, T. H., Yang, Y., Hockett, K. L., and Bull, C. T. 2019. 100 Years since tolaas: Bacterial blotch of mushrooms in the 21st century. Plant Dis. 103:2714-2732.

Osdaghi, E., Taghavi, S. M., Calamai, S., Biancalani, C., Cerboneschi, M., Tegli, S., and Harveson, R. M. 2018b. Phenotypic and molecular-phylogenetic analysis provide novel insights into the diversity of Curtobacterium flaccumfaciens. Phytopathology 108:1154-1164.

Osdaghi, E., Taghavi, S. M., Hamzehzarghani, H., Fazliarab, A., Harveson, R. M., and Lamichhane, J. R. 2016. Occurrence and characterization of a new red-pigmented variant of Curtobacterium flaccumfaciens, the causal agent of bacterial wilt of edible dry beans in Iran. Eur. J. Plant Pathol. 146: $129-145$

Osdaghi, E., Taghavi, S. M., Hamzehzarghani, H., Fazliarab, A., Harveson, R. M., Tegli, S., and Lamichhane, J. R. 2018c. Epiphytic Curtobacterium flaccumfaciens strains isolated from symptomless solanaceous vegetables are pathogenic on leguminous but not on solanaceous plants. Plant Pathol. 67:388-398.

Rainey, P. B., Brodey, C. L., and Johnstone, K. 1992. Biology of Pseudomona tolaasii, cause of brown blotch disease of the cultivated mushroom. Adv. Plant Pathol. 8:95-117.

Sajben, E., Manczinger, L., Nagy, A., Kredics, L., and Vágvölgyi, C. 2011. Characterization of pseudomonads isolated from decaying sporocarps of oyster mushroom. Microbiol. Res. 166:255-267.

Schaad, N. W., Jones, J. B., and Chun, W. 2001. Laboratory Guide for Identification of Plant Pathogenic Bacteria. APS Press, St. Paul, MN.

Schisler, L. C., Sinden, J. W., and Sigel, E. M. 1968. Etiology of mummy disease of cultivated mushrooms. Phytopathology 58:944-948.

Shen, L., Liu, Y., Yao, T., Kang, S., Wang, Y., Jiao, N., Liu, H., Zhou, Y., Xu, B., and Liu, X. 2013. Mycetocola zhadangensis sp. nov., isolated from snow. Int. J. Syst. Evol. Microbiol. 63:3375-3378. 
Shirata, A., Sugaya, K., Takasugi, M., and Monde, K. 1995. Isolation and biological activity of toxins produced by a Japanese strain of Pseudomonas tolaasii, the pathogen of bacterial rot of cultivated oyster mushroom. Ann. Phytopathol. Soc. Jpn. 61:493-502.

Stackebrandt, E., Rainey, F., and Ward-Rainey, N. L. 1997. Proposal for a new hierarchic classification system, Actinobacteria classis nov. Int. J. Syst. Bacteriol. 47:479-491.

Tolaas, A. G. 1915. A bacterial disease of cultivated mushrooms. Phytopathology 5:51-54.

Tsukamoto, T., Shirata, A., and Murata, H. 1998. Isolation of a Gram-positive bacterium effective in suppression of brown blotch disease of cultivated mushrooms, Pleurotus ostreatus and Agaricus bisporus, caused by Pseudomonas tolaasii. Mycoscience 39:273-278.

Tsukamoto, T., Takeuchi, M., Shida, O., Murata, H., and Shirata, A. 2001. Proposal of Mycetocola gen. nov. in the family Microbacteriaceae and three new species, Mycetocola saprophilus sp. nov., Mycetocola tolaasinivorans sp. nov. and Mycetocola lacteus sp. nov., isolated from cultivated mushroom, Pleurotus ostreatus. Int. J. Syst. Evol. Microbiol. 51:937-944.

Ware, W. M. 1933. A disease of cultivated mushrooms caused by Verticillium Malthousei sp. nov. Ann. Bot. 47:763-785.
Weisburg, W. G., Barns, S. M., Pelletier, D. A., and Lane, D. J. 1991. 16S ribosomal DNA amplification for phylogenetic study. J. Bacteriol. 173:697-703.

Wong, W. C., and Preece, T. F. 1979. Identification of Pseudomonas tolaasii: The white line in agar and mushroom tissue block rapid pitting tests. J. Appl. Bacteriol. 47:401-407.

Wong, W. C., and Preece, T. F. 1982. Pseudomonas tolaasii in cultivated mushroom (Agaricus bisporus) crops: Numbers of the bacterium and symptom development on mushrooms grown in various environments after artificial inoculation. J. Appl. Bacteriol. 53:87-96.

Young, J. M. 1970. Drippy gill: A bacterial disease of cultivated mushrooms caused by Pseudomonas agarici n. sp. N. Z. J. Agric. Res. 13:977-990.

Zgurskaya, H. L., Evtushenko, L. I., Akimov, V. N., and Kalakoutskii, L. V. 1993 Rathayibacter gen. nov., including the species Rathayibacter rathayi comb. nov., Rathayibacter tritici comb. nov., Rathayibacter iranicus comb. nov., and six strains from annual grass. Int. J. Syst. Bacteriol. 43:143-149.

Zhu, L., Liu, Q., Liu, H., Zhou, Y., Xin, Y., and Dong, X. 2013. Mycetocola miduiensis sp. nov., a psychrotolerant bacterium isolated from Midui glacier. Int. J. Syst. Evol. Microbiol. 63:2661-2665. 